\title{
Clinical characteristics and risk factors for mortality in COVID-19 inpatients in Birjand, Iran: a single-center retrospective study
}

Ghodsiyeh Azarkar ${ }^{1}$ and Freshteh Osmani ${ }^{1,2^{*}}$ (C)

\begin{abstract}
Background: The coronavirus disease 2019(COVID-19) has affected mortality worldwide. The Cox proportional hazard (CPH) model is becoming more popular in time-to-event data analysis. This study aimed to evaluate the clinical characteristics in COVID-19 inpatients including (survivor and non-survivor); thus helping clinicians give the right treatment and assess prognosis and guide the treatment.
\end{abstract}

Methods: This single-center study was conducted at Hospital for COVID-19 patients in Birjand. Inpatients with confirmed COVID-19 were included. Patients were classified as the discharged or survivor group and the death or nonsurvivor group based on their outcome (improvement or death). Clinical, epidemiological characteristics, as well as laboratory parameters, were extracted from electronic medical records. Independent sample $T$ test and the Chi-square test or Fisher's exact test were used to evaluate the association of interested variables. The CPH model was used for survival analysis in the COVID-19 death patients. Significant level was set as 0.05 in all analyses.

Results: The results showed that the mortality rate was about (17.4\%). So that, 62(17\%) patients had died due to COVID-19, and 298 (83.6\%) patients had recovered and discharged. Clinical parameters and comorbidities such as oxygen saturation, lymphocyte and platelet counts, hemoglobin levels, C-reactive protein, and liver and kidney function, were statistically significant between both studied groups. The results of the CPH model showed that comorbidities, hypertension, lymphocyte counts, platelet count, and C-reactive protein level, may increase the risk of death due to the COVID-19 as risk factors in inpatients cases.

Conclusions: Patients with, lower lymphocyte counts in hemogram, platelet count and serum albumin, and high C-reactive protein level, and also patients with comorbidities may have more risk for death. So, it should be given more attention to risk management in the progression of COVID-19 disease.

Keywords: Survival model, Cox model, Risk factors of death, COVID-19

\section{Background}

Coronavirus disease (COVID-19) spread in 2019, and subsequently, severe acute respiratory syndrome coronavirus $2^{1}$ broke out rapidly [1]. This modern virus is principally related to pulmonary infection, hence, it can

\footnotetext{
*Correspondence: dr.osmani68@gmail.com

${ }^{2}$ Infectious Disease Research Center, Birjand University of Medical Sciences, Birjand, Iran

Full list of author information is available at the end of the article
}

involve several organs, such as the spleen, cardiovascular, liver and stomach, and so on [2]. These patients mainly require hospitalization, intensive care unit admission, and most times need intubation [3].

In acute patients, symptoms usually develop into metabolic acidosis and multi-organ dysfunction syndrome, and it may eventually lead to death. The initial symptoms are usually dry cough, fever, and even fatigue. Also, some cases have no apparent symptoms. Recent researches declare that the most prevalent comorbidities

${ }^{1}$ (SARS-CoV-2).

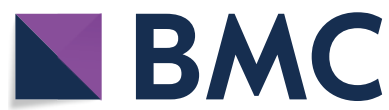

(O) The Author(s) 2021. Open Access This article is licensed under a Creative Commons Attribution 4.0 International License, which permits use, sharing, adaptation, distribution and reproduction in any medium or format, as long as you give appropriate credit to the original author(s) and the source, provide a link to the Creative Commons licence, and indicate if changes were made. The images or other third party material in this article are included in the article's Creative Commons licence, unless indicated otherwise in a credit line to the material. If material is not included in the article's Creative Commons licence and your intended use is not permitted by statutory regulation or exceeds the permitted use, you will need to obtain permission directly from the copyright holder. To view a copy of this licence, visit http://creativecommons.org/licenses/by/4.0/. The Creative Commons Public Domain Dedication waiver (http://creativeco mmons.org/publicdomain/zero/1.0/) applies to the data made available in this article, unless otherwise stated in a credit line to the data. 
in COVID-19 are diabetes, hypertension, and cardiovascular disease. Therefore, assessing patients' clinical symptoms according to current influencing factors and comorbidities is important for clinicians $[4,5]$.

The time-to-event analysis is a series of statistical analyzing methods in which, the outcome variable is time until an event occurs. A key feature in survival analysis is that not everyone will necessarily experience the event of interest within the specified time of the study, so some individuals are censored [6,7]. The key concept in survival analysis is the hazard function that describes the instantaneous risk of the event for an individual who has not already experienced the event. Such hazards can be included in survival models as Cox's proportional hazards model $[8,9]$.

Studies of the clinical and epidemiologic characteristics of COVID-19 have been conducted in many countries. As one of the first conducted studies, Huang et al. [6] revealed clinical manifestations of COVID-19 patients and concluded that intensive care unit (ICU) patients had higher plasma levels of cytokines compared with non-ICU patients. Also, other studies compared clinical non-severe patients. As result, ICU patients were significantly older and more likely to have some comorbidities $[10,11]$. Therefore, in this study, we used the Cox hazard model to provide a highly accurate risk-estimation model to guide the treatment of this disease. Moreover, the risk factors of status for COVID-19 patients were investigated among hospitalized COVID-19 patients in Birjand.

\section{Methods}

This retrospective study was conducted at a hospital in Birjand, Southeast Iran. Systematic random sampling was done from COVID-19 inpatients from 1 March to 15 November 2020. Inclusion criteria were positive realtime reverse transcriptase-polymerase chain reaction (RT-PCR) or a clinical diagnosis made by the radiological responsible clinician based on signs, symptoms, or radiology consistent with COVID-19. Also, incomplete hospital records were excluded. A checklist was provided based on previous studies $[12,13]$. These provided forms were completed by the patients' file information. Interested variables based on prognostic indicators including a history of coronary artery disease, diabetes, and hypertension; smoking status; and blood biomarkers were extracted from electronic health records. Also, laboratory and radiographic parameters were included.

\section{Outcomes}

The outcomes of the patients included improvement to discharge criteria or worsening to death. The patient discharge criteria and clinical type were based on COVID19 diagnosis and treatment protocol version 7 [14].
COVID-19 death was defined as mortality for COVID19 patients who die as a direct result of coronavirus infection but not patients who die indirectly as a result of the pandemic [15].

Hospitalization was defined as stay in a hospital for at least one day, so outpatients were not included. Due to time is in discrete days, at time zero, survival is $100 \%$.

\section{Statistical analysis}

Statistical analysis was done by SPSS.21 and R.3.2.2 software. First, the collected data were cleaned and the accuracy of the data was checked in partnership with the medical record office. The quantitative data were described by mean \pm standard deviation; also, qualitative data described by frequency and percent. To compare groups, Chi-square test or Fisher's exact test was used. To analyze whether the included variables and comorbidities were predictive of inpatients mortality, a multivariable analysis as a Cox proportional hazards model to identify risk factors associated with survival of COVID-19 patients were fitted. Also, log rank test was used for comparison of survival time by categorical variables. A $p<0.05$ was considered statistically significant. The packages "survival" and "cmprsk" were used in the analysis.

\section{Ethics approval}

The requirement for written informed consent was waived in consideration of emerging infectious diseases. All procedures in this study were approved by the Ethical Committee of Birjand University of Medical Sciences, reference number: IR.BUMS.REC.1399.185.

\section{Results}

Demographic characteristics and laboratory parameters

From 20 May to 20 September 2020, a total of 360 patients diagnosed with COVID-19 were included after the exclusion of patients with no clinical record or missingness in the diagnosis record.

The mean age was $42 \pm 3.46$ years (minimum 23, maximum 97 years), minimum follow-up time was 2 days and the maximum follow-up time was 46 days and $52.4 \%$ were men. The overall mean (SD) of the patient's survival time was 16.4 (1.3) days. The median survival time for dead patients was 8 days (IQR 5-13). 313 patients were discharged. The median length of hospital stay for those patients was 10 days (IQR 4-15; Table 1).

According to the outcome, we divided the patients into two groups (the discharged group and the death group). Most of them had a low and moderate fever. A higher proportion of patients in the discharged group was referred to the hospital within 7 days of the onset of symptoms to treatment, as opposed to cases in the 
Table 1 Descriptive analysis of continuous demographic and clinical data details for patients in the hospital

\begin{tabular}{|c|c|c|c|c|c|c|c|}
\hline Variables & Min & Q1 & Median & Mean & SD & Q3 & Max \\
\hline LOS (days) & 1.00 & 3.00 & 4.00 & 4.28 & 1.64 & 5.00 & 16 \\
\hline $\mathrm{BMI}, \mathrm{kg} / \mathrm{m}^{2}$ & 19.8 & 21.2 & 23 & 23.03 & 6.39 & 25.68 & 27.6 \\
\hline Age (years) & 23 & 34.9 & 42.26 & 46.50 & 12.81 & 58.06 & 97 \\
\hline WBC $\left(10^{3} \mu \mathrm{L}\right)$ & 0.60 & 2.80 & 4.10 & 4.96 & 1.82 & 6.10 & 42.80 \\
\hline $\mathrm{RBC}\left(10^{6} \mu \mathrm{L}\right)$ & 1.96 & 4.35 & 4.77 & 4.78 & 0.97 & 5.18 & 8.06 \\
\hline $\mathrm{HGB}(\mathrm{g} / \mathrm{dl})$ & 5.70 & 12.00 & 13.20 & 13.24 & 3.26 & 14.60 & 18.20 \\
\hline HCT (\%) & 18 & 36 & 40 & 39.61 & 10.88 & 43 & 61 \\
\hline
\end{tabular}

$\mathrm{g} / \mathrm{dl}$ grams per deciliter; $1 \mu \mathrm{L} 1$ cell per microliter $=1$ cell per cubic millimeter $\left(\mathrm{mm}^{3}\right)$

other group, who this period was more than 7 days from symptom onset to come to the hospital. The mean age of patients in the discharged group and death group were $68.00 \pm 9.53$ vs $41.36 \pm 12.09$ ), respectively. So that a significant difference was observed $(p<0.001)$.

COVID-19 cases in the death group had higher rates of upper respiratory symptoms, dyspnea, muscle pain, gastrointestinal symptoms, and comorbidities. Among clinical symptoms, significant differences were obtained in upper respiratory tract symptoms and dyspnea. Moreover, concerning sex, there were a higher proportion of males in the death group than that in the discharged group, and with a statistically significant difference. All these reports are summarized in Table 2.

There were observed statistically significant differences in the majority of laboratory characteristics except for sodium and potassium between both studied groups ( $p<$ $0.05)$. Also, death group patients had lower platelet count and lower oxygen saturation; in contrast, these patients had higher lymphocyte count and higher WBC. Liver enzymes (AST and ALT), and blood urea nitrogen was higher in the death group, illustrating that these patients have organ dysfunction to a different extent. These results are presented in Table 3.

\section{Survival analysis}

The hospital mortality rate for COVID-19 inpatients was $17 \%$. The mortality rate was higher among the older patients with a more comorbidities, such as diabetes and hypertension. Results of the $\mathrm{CPH}$ regression model showed that the hazard of mortality was significantly increased in upper respiratory symptoms, hypertension, pulmonary comorbidities, platelet count lower than 100, serum albumin lower than $35 \mathrm{~g} / \mathrm{L}, 25$-hydroxyvitamin D levels, and serum urea nitrogen more than $8 \mathrm{mmol} / \mathrm{L}$ patients. Most non-survivor patients were admitted to the ICU. So that, the hazard ratio for mortality was significantly higher in patients requiring ICU admission $(p<0.0001)$.
The survival curves based on WBC count, age group, lymphocyte count, and C-reactive protein and blood urea nitrogen are shown in Fig. 1.

\section{Discussion}

SARS-CoV-2 known as a human coronavirus is mainly transmitted by droplets and also through aerosols. The median incubation period is $4-5$ days, and in the majority of them, about 12 days after infection, the symptoms gradually develop. Early in the pandemic, the period between clinical symptoms onset to progression to death is on average 14 days. Furthermore, the mortality rate was very variable at different times and area to area. This variation may be due to virus variation, besides regional differences. On the other hand, the number of patients exponentially increases. The hyperinflammatory response triggered by SARS-CoV-2 is the main reason for the death of patients [15]. Among these patients, the most usual symptoms are fever and cough, and some other patients present with sneezing; and only a few patients develop nausea or diarrhea [4]. Also, there are cases with no symptoms or tend to improve after the infection. In return, some patients appear with a fast progression, like respiratory failure or even death [14]. Also, the fatality rate significantly increased in cardiovascular patients and also patients with hypertension and diabetes [16]. Mortality increases mostly with the progression of the disease. In this study, some relevant factors and outcomes of COVID-19 inpatients were analyzed in Birjand, East of Iran to guide the treatment and prognosis of these inpatients. All included patients were classified into two categories (improved or dead) based on their disease outcome. There was a significant difference in the mean age of the two groups, indicating that older age is a risk indicator for this disease, which is often accompanied by the type of comorbidities. Previous studies showed that old age patients with comorbidities were more likely to experience a very severe phase of the disease [17]. Pathological examination showed that lesions involved multiple organs in severe patients. Some studies 
Table 2 Comparison of clinical parameters and comorbidities in the both groups

\begin{tabular}{|c|c|c|c|c|}
\hline $\begin{array}{l}\text { Clinical parameters and } \\
\text { comorbidities }\end{array}$ & $\begin{array}{l}\text { Discharged patients }(n= \\
\text { 298) }\end{array}$ & Death $(n=62)$ & Total $(n=360)$ & $p$ \\
\hline \multicolumn{5}{|l|}{ Age (years) } \\
\hline$<60$ years & $226(75.7 \%)$ & $17(27.1 \%)$ & 199 (55.2\%) & \multirow[t]{2}{*}{$<0.00$} \\
\hline$>60$ years & $72(24.3 \%)$ & $45(72.9 \%)$ & 161 (44.8\%) & \\
\hline \multicolumn{5}{|l|}{ Sex } \\
\hline Male & $134(45 \%)$ & $37(59.6 \%)$ & $184(51.0 \%)$ & \multirow[t]{2}{*}{0.023} \\
\hline Female & 164 (55\%) & $25(40.4 \%)$ & 176 (49.0\%) & \\
\hline \multicolumn{5}{|l|}{ URS } \\
\hline Yes & $164(55 \%)$ & $53(86.4 \%)$ & 245 (68.2\%) & \multirow[t]{2}{*}{0.033} \\
\hline No & $134(45 \%)$ & $9(13.6 \%)$ & 115 (31.8\%) & \\
\hline \multicolumn{5}{|l|}{ Dyspnea } \\
\hline Yes & 113 (37.9\%) & $39(62.6 \%)$ & 169 (46.9\%) & \multirow[t]{2}{*}{$<0.001$} \\
\hline No & $185(62.1 \%)$ & $23(37.4 \%)$ & 191 (51.9\%) & \\
\hline \multicolumn{5}{|l|}{ Headache } \\
\hline Yes & $28(9.3 \%)$ & $7(11.1 \%)$ & $36(10.0 \%)$ & \multirow[t]{2}{*}{0.072} \\
\hline No & 270 (90.7\%) & 55 (88.9\%) & 324 (90.0\%) & \\
\hline \multicolumn{5}{|l|}{ Hypertension } \\
\hline Yes & $39(12.9 \%)$ & $29(46.5 \%)$ & $96(26.8 \%)$ & \multirow[t]{2}{*}{$<0.001$} \\
\hline No & 259 (87.1\%) & $33(53.5 \%)$ & $263(73.2 \%)$ & \\
\hline \multicolumn{5}{|l|}{ Diabetes } \\
\hline Yes & 24 (7.9\%) & $13(20.2 \%)$ & $47(13.0 \%)$ & \multirow[t]{2}{*}{$<0.001$} \\
\hline No & 274 (92.1\%) & $49(79.8 \%)$ & $313(87.0 \%)$ & \\
\hline \multicolumn{5}{|l|}{ Coronary heart disease } \\
\hline Yes & $9(2.9 \%)$ & $11(17.5 \%)$ & $32(8.8 \%)$ & \multirow[t]{2}{*}{0.014} \\
\hline No & 289 (97.1\%) & $51(82.5 \%)$ & $328(91.2 \%)$ & \\
\hline \multicolumn{5}{|l|}{ Pulmonary comorbidities } \\
\hline Yes & $15(5 \%)$ & $7(12.1 \%)$ & $29(7.9 \%)$ & \multirow[t]{2}{*}{0.32} \\
\hline No & $283(95 \%)$ & $55(87.9 \%)$ & 331 (92.1\%) & \\
\hline \multicolumn{5}{|l|}{ Time to admission (days) } \\
\hline$>6$ & $130(43.6 \%)$ & $43(68.7 \%)$ & 194 (54.0\%) & \multirow[t]{2}{*}{$<0.001$} \\
\hline$\leq 6$ & $168(56.4 \%)$ & $19(31.3 \%)$ & $166(46.0 \%)$ & \\
\hline \multicolumn{5}{|l|}{ Hospital days (days) } \\
\hline$>7$ & $249(83.6 \%)$ & $16(26.3 \%)$ & $215(59.8 \%)$ & \multirow[t]{2}{*}{$<0.001$} \\
\hline$\leq 7$ & $48(16.4 \%)$ & $45(73.7 \%)$ & 144 (40.2\%) & \\
\hline
\end{tabular}

URS upper respiratory symptoms; $p p$ value

have reported that COVID-19 patients reveal coagulation abnormalities $[18,19]$. In most cases, mild thrombocytopenia is observed in 5-41.7\% of patients with COVID-19 [20]. A study showed that severe patients had a lower platelet count than non-severe cases. Moreover, the non-survivor patients had a lower platelet count than the survivors' ones [21]. Platelets with having a substantial role in combining thrombotic and immune recruitment functions can prevent microbial invasion. Studies have shown that inflammatory markers are risk factors in COVID-19 patients [22]. Factors, such as high levels of lymphocytosis, and mononuclear macrophage infiltration, are significant markers for the rapid progression of the COVID-19 disease [23]. The current study indicated significant differences in WBC counts, and lymphocyte counts between the studied groups.

Survival analysis in this study showed that factor, such as blood urea nitrogen, was associated with a hazard of death. Also, there were significant differences in the mean value of urea nitrogen and creatinine between these groups. Another study showed that $5.1 \%$ of patients reported acute kidney injury [24]. The mechanism may be associated with the infiltration of lymphocytes in renal tissue. COVID-19 patients with renal dysfunction will have a higher risk of death, offering that efficacious renal function control should be considered in the clinical treatment. 
Table 3 Comparison of laboratory parameters in studied groups

\begin{tabular}{|c|c|c|c|}
\hline \multirow[t]{2}{*}{ Laboratory parameters } & \multicolumn{2}{|l|}{$n=360$} & \multirow[t]{2}{*}{$p$ value } \\
\hline & Discharged patients $(n=298)$ & Death group $(n=62)$ & \\
\hline $\mathrm{SaO}_{2}(\%)$ & $93.08 \pm 9.26$ & $87.12 \pm 9.09$ & $<0.001$ \\
\hline Hemoglobin (g/L) & $129.36 \pm 19.36$ & $122.39 \pm 20.33$ & 0.025 \\
\hline $\mathrm{WBC}\left(\times 10^{9} / \mathrm{L}\right)$ & $5.77 \pm 2.37$ & $9.44 \pm 6.13$ & $<0.001$ \\
\hline Lymphocytes (× 109/L) & $1.15 \pm 0.69$ & $0.59 \pm 0.29$ & $<0.001$ \\
\hline Platelet count $\left(\times 10^{9} / \mathrm{L}\right)$ & $198 \pm 66.22$ & $163.21 \pm 84.97$ & 0.001 \\
\hline C-reactive protein (mg/L) & $98.79 \pm 43.88$ & $19.39 \pm 17.36$ & $<0.001$ \\
\hline Serum albumin (g/L) & $39.47 \pm 18.36$ & $32.45 \pm 4.71$ & 0.002 \\
\hline $\mathrm{ALP}(\mathrm{U} / \mathrm{L})$ & $60.26 \pm 19.44$ & $82.91 \pm 49.97$ & $<0.001$ \\
\hline AST (U/L) & $27.74 \pm 17.07$ & $55.19 \pm 39.96$ & 0.001 \\
\hline $\operatorname{ALT}(U / L)$ & $26.48 \pm 24.64$ & $38.73 \pm 34.04$ & $<0.001$ \\
\hline Urea $(\mathrm{mmol} / \mathrm{L})$ & $4.68 \pm 2.06$ & $8.93 \pm 4.37$ & $<0.001$ \\
\hline Creatinine (g/L) & $65.84 \pm 19.72$ & $129.56 \pm 29.96$ & 0.007 \\
\hline $\mathrm{LDH}(\mathrm{U} / \mathrm{L})$ & $247.33 \pm 87.00$ & $486.21 \pm 129.05$ & $<0.001$ \\
\hline Serum sodium (mmol/L) & $129.96 \pm 14.25$ & $137.88 \pm 14.17$ & 0.179 \\
\hline Serum potassium (mmol/L & $3.71 \pm 0.36$ & $3.85 \pm 1.06$ & 0.112 \\
\hline
\end{tabular}

$W B C$ white blood cell; $A S T$ alanine aminotransferase; $A L B$ serum albumin; $A L P$ alkaline phosphatase; $A L T$ alanine aminotransferase; $L D H$ lactate dehydrogenase

In addition, serum albumin levels somewhat reflect the body's immune state. So a bad nutritional status can lead to lower serum albumin levels, which are detrimental to antibody production and virus clearance $[7,25]$. Therefore, it should be seriously considered. Recently a study released that poor nutrition can be an effective risk factor for severe COVID-19 disease [26]. Malnutrition and anorexia probably increase the hazard of respiratory failure. This finding suggests the optimum treatment strategy in advance for older COVID-19 patients. Since the epidemic of COVID19 , much literature has reported that older age was correlated with ARDS after being infected [27]. Mortality in our study was $17 \cdot 2 \%$, which is in line with current mortality estimates for COVID-19 globally. A study recently showed a mortality rate of $26 \%$ in a large UK study [28]. In this study, we fitted the $\mathrm{CPH}$ model to estimate the adjusted hazard of COVID-19 inpatients. Our results showed that a higher age group has a direct effect on the hazard of death. These results are consistent with another study [29]. The findings represent that the increased mortality associated with increased C-reactive protein levels and prevalence of comorbidities (hypertension, diabetes, etc.) are also in line with other estimates, suggesting that our data are comparable with other populations [30, 31].

\section{Conclusion}

This epidemic carries on. So, the challenges are still horrific. Evaluation of the risk factors of this disease can be beneficial for clinicians to figure out the risk of disease progression, to perform proper and efficient intervention earlier to get the best therapeutic goal, although we feel that it can be useful, in conjunction with other prognostic markers regarding clinical management decisions.

\section{Limitation}

However carefully we prepared this study, still we had a few limitations in our study. First, our data were singlecenter and the sample size was not too large to demonstrate all infected people. Surely, subjective outcomes like pain may affect the assessment of our findings and lead to bias in the results. Second, patients without access to treatment were not included. Therefore, these results are only generalizable to the inpatients' population. Also, there are missing observations in some of the recorded factors. It is possible that inaccuracies may have occurred during data collection, although our research team is experienced in collecting data.

(See figure on next page.)

Fig. 1 Survival curves probability based on risk factors. Survival probability in COVID-19 inpatients in different range of white blood cell (A), lymphocyte count $(\mathbf{B})$, neutrophil counts $(\mathbf{C})$, age $(\mathbf{D})$, blood urea nitrogen $(\mathbf{E})$ and C-reactive protein $(\mathbf{F})$. WBC white blood cell; Neu neutrophil counts; Lym lymphocyte count; AST alanine aminotransferase; ALB serum albumin; BUN blood urea nitrogen; CRP C-reactive protein; PLT platelet count 

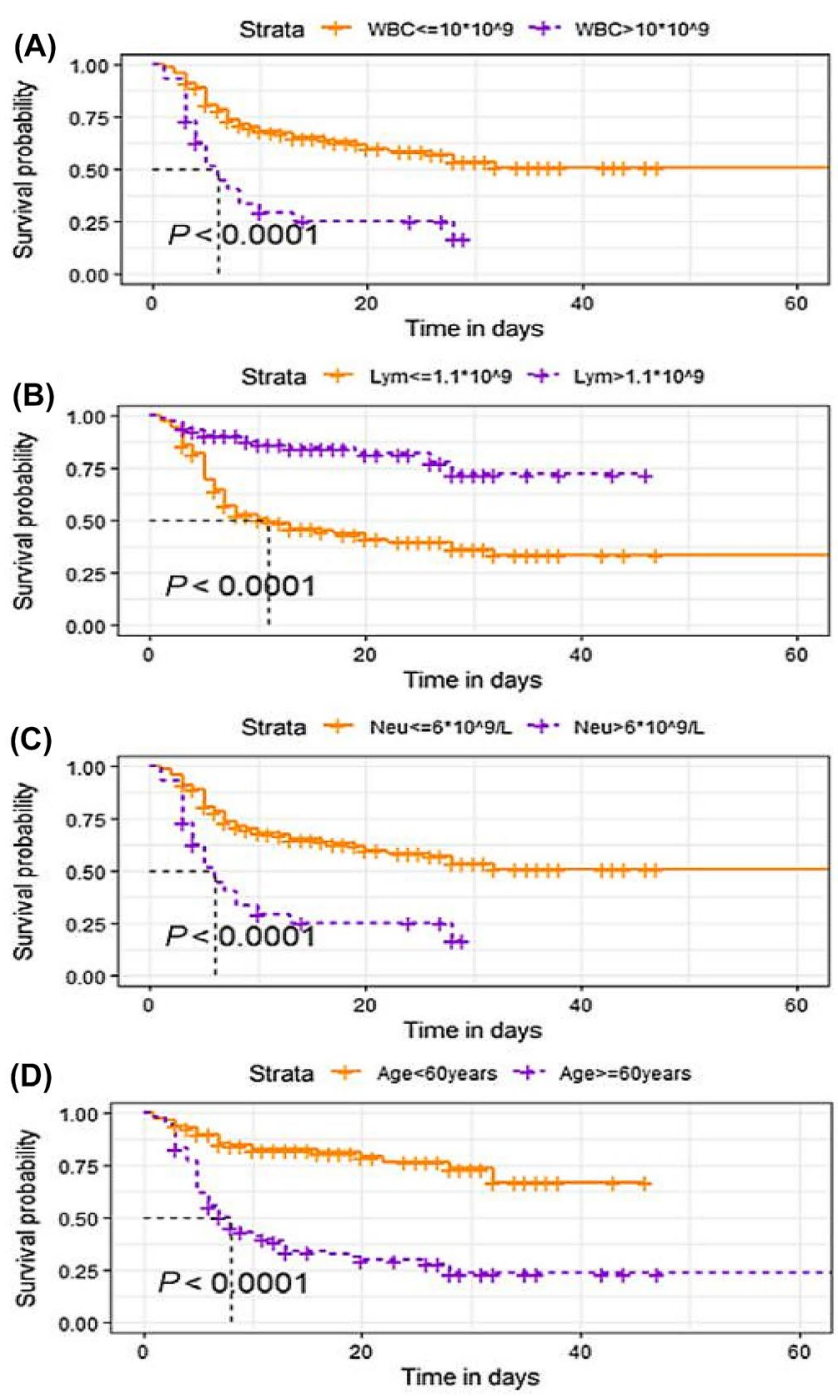

(E) Strata + BUN $<=8 \mathrm{mmoll}+-$ BUN $>8 \mathrm{mmoll}$
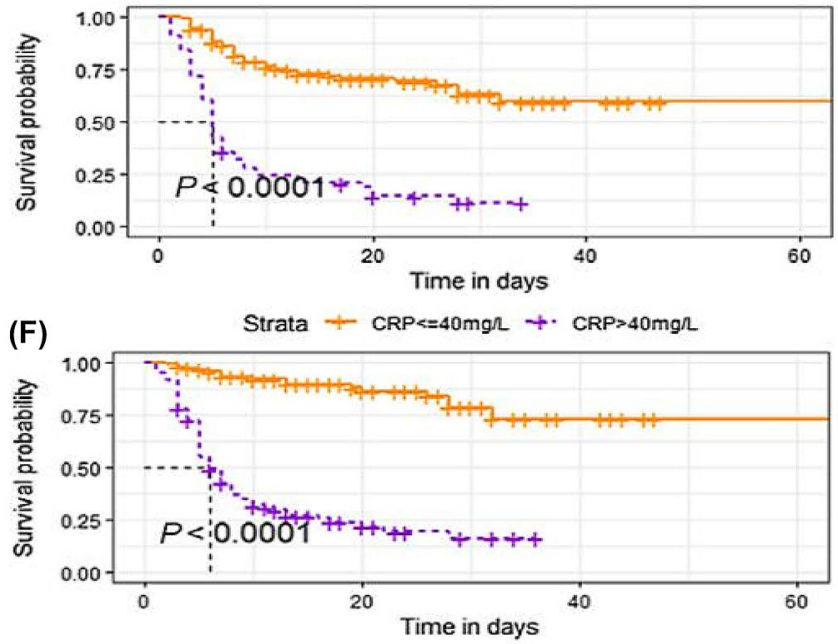

Fig. 1 (See legend on previous page.) 


\section{Abbreviations}

WBC: White blood cell; Neu: Neutrophil counts; Lym: Lymphocyte count; AST: Alanine aminotransferase; ALB: Serum albumin; BUN: Blood urea nitrogen; CRP: C-reactive protein; PLT: Platelet count; $\mathrm{CPH}$ : Cox proportional hazard.

\section{Acknowledgements}

We would like to thank all the students for their participation.

\section{Authors' contributions}

GHA and FO designed the experiments. FO collected data and performed the statistical analyses and wrote the results section. FO interpreted the results. FO wrote the initial manuscript. GHA critically reviewed and modified the manuscript. Both authors read and approved the final manuscript.

\section{Funding}

No funding.

\section{Availability of data and materials}

The datasets used and/or analyzed during the current study are available from the corresponding author on reasonable request.

\section{Declarations}

\section{Ethics approval and consent to participate}

All procedures in this study were approved by the ethics board committee of Birjand University of Medical Sciences, reference number: IR.BUMS REC.1399.185 and consent to participate is not applicable.

\section{Consent for publication}

Not applicable.

\section{Competing interests}

The authors declare that they have no competing interests.

\section{Author details}

${ }^{1}$ Department of Biostatistics and Epidemiology, Faculty of Health, Birjand University of Medical Sciences, Birjand, Iran. ${ }^{2}$ Infectious Disease Research Center, Birjand University of Medical Sciences, Birjand, Iran.

Received: 11 May 2021 Accepted: 13 July 2021

Published online: 21 July 2021

\section{References}

1. Shahid Z, Kalayanamitra R, McClafferty B, Kepko D, Ramgobin D, Patel R, et al. COVID-19 and older adults: what we know. J Am Geriatr Soc 2020;68(5):926-9.

2. Huang C, Wang Y, Li X, Ren L, Zhao J, Hu Y, et al. Clinical features of patients infected with 2019 novel coronavirus in Wuhan, China. Lancet 2020:395(10223):497-506.

3. Guan W-J, Ni Z-Y, Hu Y, Liang W-H, Ou C-Q, He J-X, et al. Clinical characteristics of coronavirus disease 2019 in China. N Engl J Med. 2020;382(18):1708-20.

4. De Vito A Geremia N, Fiore V, Princic E, Babudieri S, Madeddu G Clinical features, laboratory findings and predictors of death in hospitalized patients with COVID-19 in Sardinia, Italy. Eur Rev Med Pharmacol Sci. 2020;24(14):7861-8.

5. Vaira LA, Deiana G, Fois AG, Pirina P, Madeddu G, De Vito A, et al. Objective evaluation of anosmia and ageusia in COVID-19 patients: singlecenter experience on 72 cases. Head Neck. 2020;42(6):1252-8.

6. Zhou F, Yu T, Du R, Fan G, Liu Y, Liu Z, et al. Clinical course and risk factors for mortality of adult inpatients with COVID-19 in Wuhan, China: a retrospective cohort study. Lancet. 2020;395(10229):1054-62.

7. Osman F. Statistical ambiguities in epidemics of coronavirus disease 2019 (COVID-19). Acta Med Iran. 2020. https://doi.org/10.18502/acta. v58i3.3780

8. Hewitt J, Carter B, McCarthy K, Pearce L, Law J, Wilson F, et al. Frailty predicts mortality in all emergency surgical admissions regardless of age. Obs Study Age Ageing. 2019;48(3):388-94.
9. Tian J, Yuan X, Xiao J, Zhong Q, Yang C, Liu B, et al. Clinical characteristics and risk factors associated with COVID-19 disease severity in patients with cancer in Wuhan, China: a multicentre, retrospective, cohort study. Lancet Oncol. 2020;21(7):893-903.

10. Farrell TW, Ferrante LE, Brown T, Francis L, Widera E, Rhodes R, et al. AGS position statement: resource allocation strategies and age-related considerations in the COVID-19 era and beyond. J Am Geriatr Soc. 2020;68(6):1136-42.

11. Osmani F. Analysis of students satisfaction with virtual education in Medical Science University during the pandemic outbreak of COVID-19. Int J Assess Tools Educ. 2021;8(1):1-8.

12. Baratella E, Crivelli P, Marrocchio C, Bozzato AM, Vito AD, Madeddu G, et al. Severity of lung involvement on chest X-rays in SARS-coronavirus-2 infected patients as a possible tool to predict clinical progression: an observational retrospective analysis of the relationship between radiological, clinical, and laboratory data. J Bras Pneumol. 2020. https://doi.org/ 10.36416/1806-3756/e20200226.

13. Ye Z, Zhang $Y$, Wang $Y$, Huang Z, Song B. Chest CT manifestations of new coronavirus disease 2019 (COVID-19): a pictorial review. Eur Radiol. 2020;30(8):4381-9.

14. Commission NH. Diagnosis and treatment protocol for novel coronavirus pneumonia (Trial version 8). Chin Med J. 2020. https://doi.org/10.1097/ CM9.0000000000000819.

15. Meo SA, Abukhalaf AA, Alomar AA, AIMutairi FJ, Usmani AM, Klonoff DC. Impact of lockdown on COVID-19 prevalence and mortality during 2020 pandemic: observational analysis of 27 countries. Eur J Med Res. 2020;25(1):1-7.

16. Lu W, Yu S, Liu H, Suo L, Tang K, Hu J, et al. Survival analysis and risk factors in COVID-19 patients. Disaster Med Public Health Prep. 2021. https://doi. org/10.1017/dmp.2021.82.

17. Ghahramani S, Tabrizi R, Lankarani KB, Kashani SMA, Rezaei S, Zeidi N, et al. Laboratory features of severe vs. non-severe COVID-19 patients in Asian populations: a systematic review and meta-analysis. Eur J Med Res. 2020;25(1):1-10.

18. Chu Y, Yang J, Shi J, Zhang P, Wang X. Obesity is associated with increased severity of disease in COVID-19 pneumonia: a systematic review and meta-analysis. Eur J Med Res. 2020;25(1):1-15.

19. Osmani F, Azarkar G. Fitting logistic regression models to assess vitamin D deficiency with clinical parameters in chronic hepatitis B patients. Infect Dis Model. 2021;6:612-7.

20. Yang $X$, Yang $Q$, Wang $Y, W u Y, X u$ J, Yu Y, et al. Thrombocytopenia and its association with mortality in patients with COVID-19. J Thromb Haemost. 2020;18(6):1469-72.

21. Jiang $S Q$, Huang QF, Xie WM, Lv C, Quan XQ. The association between severe COVID-19 and low platelet count: evidence from 31 observational studies involving 7613 participants. Br J Haematol. 2020;190(1):e29-33.

22. Wu C, Chen X, Cai Y, Zhou X, Xu S, Huang H, et al. Risk factors associated with acute respiratory distress syndrome and death in patients with coronavirus disease 2019 pneumonia in Wuhan, China. JAMA Intern Med. 2020;180(7):934-43

23. Osmani F. Problems with the accurate reporting of COVID-19 statistics in Iran. Gastroenterol Hepatol Bed Bench. 2020;13(4):275.

24. Cheng Y, Luo R, Wang $K$, Zhang M, Wang Z, Dong L, et al. Kidney disease is associated with in-hospital death of patients with COVID-19. Kidney Int. 2020;97(5):829-38.

25. Bourgonje AR, Abdulle AE, Timens W, Hillebrands JL, Navis GJ, Gordijn SJ, et al. Angiotensin-converting enzyme 2 (ACE2), SARS-CoV-2 and the pathophysiology of coronavirus disease 2019 (COVID-19). J Pathol. 2020;251(3):228-48

26. Osmani F. Problems with reporting accuracy in COVID-19 statistics in Iran. Gastroenterol Hepatol Bed Bench. 2020;13:275.

27. Caccialanza R, Lobascio F, Masi S, Crotti S, Cereda E. Early nutritional supplementation in non-critically ill coronavirus disease 2019 (COVID-19) patients. Nutrition. 2020. https://doi.org/10.1016/j.nut.2020.111050.

28. Muscedere J, Waters B, Varambally A, Bagshaw SM, Boyd JG, Maslove D, et al. The impact of frailty on intensive care unit outcomes: a systematic review and meta-analysis. Intensive Care Med. 2017;43(8):1105-22.

29. Grasselli G, Zangrillo A, Zanella A, Antonelli M, Cabrini L, Castelli A, et al. Baseline characteristics and outcomes of 1591 patients infected with SARS-CoV-2 admitted to ICUs of the Lombardy region. Italy Jama. $2020 \cdot 323(16): 1574-81$. 
30. Smith M, Hayward S, Innes S, Miller A. Point-of-care lung ultrasound in patients with COVID-19-a narrative review. Anaesthesia. 2020;75(8):1096-104.

31. Onder G, Rezza G, Brusaferro S. Case-fatality rate and characteristics of patients dying in relation to COVID-19 in Italy. JAMA. 2020;323(18):1775-6.

\section{Publisher's Note}

Springer Nature remains neutral with regard to jurisdictional claims in published maps and institutional affiliations.
Ready to submit your research? Choose BMC and benefit from:

- fast, convenient online submission

- thorough peer review by experienced researchers in your field

- rapid publication on acceptance

- support for research data, including large and complex data types

- gold Open Access which fosters wider collaboration and increased citations

- maximum visibility for your research: over $100 \mathrm{M}$ website views per year

At BMC, research is always in progress.

Learn more biomedcentral.com/submissions 